\title{
Effects of COVID-19 Lockdown And Unlock On Health of Tropical Large River With Associated Human Health Risk
}

\section{Baisakhi Chakraborty}

Raja Narendra Lal Khan Women's College

\section{Biswajit Bera}

Sidho-Kanho-Birsha University

\section{Partha Pratim Adhikary}

ICAR- Water Resources Research Institute

\section{Sumana Bhattacharjee}

University of Calcutta

\section{Sambhunath Roy}

Raja Narendra Lal Khan Women's College

\section{Soumik Saha}

University of Calcutta

\section{Debashish Sengupta}

IIT KGP: Indian Institute of Technology Kharagpur

Pravat K Shit ( $\sim$ pravatgeo2007@gmail.com)

Raja Narendra Lal Khan Women's College https://orcid.org/0000-0001-5834-0495

\section{Research Article}

Keywords: Heavy Metal Pollution Index (HPI), Human health hazard, Pearson's correlation coefficient, Hierarchical cluster analysis

Posted Date: August 9th, 2021

DOl: https://doi.org/10.21203/rs.3.rs-698177/v1

License: (c) (i) This work is licensed under a Creative Commons Attribution 4.0 International License. Read Full License

Version of Record: A version of this preprint was published at Environmental Science and Pollution Research on January 15th, 2022. See the published version at https://doi.org/10.1007/s11356-02117881-w. 

1 Effects of COVID-19 lockdown and unlock on health of tropical large river

2 with associated human health risk

3

4 Authors:

5

Baisakhi Chakraborty $^{1}$; Biswajit Bera ${ }^{2}$; Partha Pratim Adhikary ${ }^{3}$; Sumana Bhattacharjee ${ }^{4}$; Sambhunath Roy ${ }^{1}$; Soumik Saha ${ }^{4}$; Debashish Sengupta ${ }^{5}$; and Pravat Kumar Shit ${ }^{1 *}$

7

8

1. Baisakhi Chakraborty

9

PG Department of Geography, Raja N. L. Khan Women's College (Autonomous), Gope Palace, Midnapore-721102, West Bengal, India

Email: bchakraborty201595@gmail.com

\section{Biswajit Bera}

Department of Geography, Sidho Kanho Birsha University,Purulia, India

Email: biswajitbera007@gmail.com

\section{Partha Pratim Adhikary}

ICAR Indian Institute Water Management, Bhubaneswar - 751023, Odisha, India

Email: ppadhikary@gmail.com

\section{Sumana Bhattacharjee}

Department of Geography, University of Calcutta, 35, Ballygunge Circular Road, Ballygunge,

Kolkata 700019, India

Email: sumana.aarohi@gmail.com

\section{Sambhunath Roy}

PG Department of Geography, Raja N. L. Khan Women's College (Autonomous), Gope Palace, Midnapore-721102, West Bengal, India

Email: sambhuroynath95@gmail.com

\section{Soumik Saha}

Department of Geography, University of Calcutta, 35, Ballygunge Circular Road, Ballygunge,

Kolkata 700019, India

Email: soumiksaha577@gmail.com

\section{Debashish Sengupta}

Department of Geology \& Geophysics, Indian Institute of Technology (IIT), Kharagpur-721302, (West Bengal), India.

E-mail: dsgg@gg.iitkgp.ac.in 


\section{Pravat Kumar Shit}

PG Department of Geography, Raja N. L. Khan Women's College (Autonomous), Gope Palace, Midnapore-721102, West Bengal, India

Email: pravatgeo2007@gmail.com

\section{*Corresponding author Name: Pravat Kumar Shit}

Corresponding author Email: pravatgeo2007@gmail.com

\section{Abstract}

From the last month of 2020, sudden outbreak of novel corona virus caused socio-economic lockdown in many countries. Many studies proved that temporary shutdown of economic sectors helped to recover river water quality. Perhaps, for the first time, this present study is conducted in an industrially and agriculturally influenced catchment of river Damodar, India. This research was fixed some relevant objectives like (i) to evaluate the changes of heavy metals $(\mathrm{Zn}, \mathrm{Cd}, \mathrm{Pb}, \mathrm{Ni}, \mathrm{Cr}$ and $\mathrm{Fe}$ ) and microbial contamination (TVC, TC and FC) of river water (ii) to identify the magnitude of human health hazard during lockdown compared to pre lockdown and unlock phase. Total 33 water samples were collected in three periods. During lockdown, TVC, TC and FC showed the gradual decreasing trend in this stretch. All samples exceed the concentration of microbes compared to recommended standard in three periods. Among all heavy metals, Zinc, iron, chromium found their abandoned presence in the river water. Heavy Metal Pollution Index (HPI) showed 100\% sample water of highly polluted (HPI > 150) type for drinking and other purpose. During lockdown, HPI showed around $54.54 \%$ sample changed to lower pollution and $45.45 \%$ changed to medium pollution level. During unlock phase, $45.45 \%$ samples again changed to high pollution. Pearson's correlation coefficient and hierarchical cluster analysis indicated strong relation among heavy metals with fecal coliform in this river. This suggests high possibilities of common source of contamination (wastes of iron and steel plant, chemical plant, cement factories, agricultural runoff, municipal sewages etc) in river bed. No carcinogenic Hazard Index (HI) values of ingestion by children indicated higher potentiality to health risk $(\mathrm{HI}>1)$ in all samples of three periods and during lockdown, 36.36\% samples showed no possible health risk for adults $(\mathrm{HI}<1)$. HI of dermal contact showed no possible health risk for children and adults in three periods. This assessment strongly recommended scientific and cheep management techniques to control water pollution and related health hazard in the study area.

Keywords: Heavy Metal Pollution Index (HPI); Human health hazard; Pearson's correlation coefficient; Hierarchical cluster analysis 


\section{Introduction}

It has now become a great environmental issue that deterioration of surface water quality is being increasing day by day worldwide (John et al., 2014; Zhaoshi et al., 2017). Increasing pollution load of industrial, urban, agricultural and transport declines the natural quality of surface water (Karunanidhi et al., 2020; Zou et al., 2018). Pollution of water resources brings negative impact on ecological condition, aquatic bio-diversity and also human health (Ouyang et al., 2006). Heavy metals are considered as one of the major contaminants of surface water pollution in many parts of the world (Ali and Khan, 2018; Tiwari et al., 2015). From the past few decades, aquatic environment is being faced by hazardous heavy metals. Some heavy metals are naturally originated by weathering of parent rocks. But, accelerating rate of mining, industrials waste discharge, fossil fuel burning, metallurgical waste disposal, usages of pesticides, fertilisers etc promotes the toxic metal contamination to the aquatic environment. Mixing of heavy metals with water will bring serious negative effects on utilisation of household water, agro-farming, industrial or urban purposes (Akhilesh et al., 2009). Toxicity of heavy metals could exist for a longer time period in environment and therefore it leads to hazardous impact on living organisms (Yahaya et al., 2009; Klavins et al., 2000; Tam and Wong, 2000; Hakan 2006). Many studies have found the potential adverse impact of heavy metals on human health (Giuliano et al., 2007). Long period intake of manganese, zinc, chromium with drinking water can cause neurosis, chlorosis type chronic diseases in human body (Tumuklu et al., 2007). Higher intake of iron with drinking water may lead to gastrointestinal disorder (Rezaei et al., 2017). Excess concentration of nickel in drinking water damages lungs and nasal organ, and it can also reduce body weight, heart affectivity etc (USEPA 1995). Higher intake of lead with drinking water rises blood pressure, muscle pain, kidney problem etc (Sekar and Suriyakala, 2016). Thus, excess consumption of heavy metals can cause non carcinogenic or carcinogenic type health hazards in affected areas (Mohammadi et al., 2019; Kavcar et al., 2009; Sun et al., 2007). Increasing contamination of heavy metals promotes resistance power of bacteriological activities in surface water. Municipal wastes, pathological wastes and agricultural runoff are the major supply sources of micro - organisms in surface water (Besharati et al., 2018). These microorganisms can cause bacterial contamination in human body and it may lead to severe infections (Rahube and Yost, 2010). Therefore, control on pollutants contamination to water 
and supply of safe drinking water become a vital contemporary challenge to the world especially for developing countries.

At the end of December, 2019 sudden outbreak of corona virus very rapidly transformed to the pandemic condition in all over the world. As a result, more than 179 million active cases and nearly 3.8 million death cases from all over the world have been reported by WHO (World Health Organisation) till last week of June, 2021. In India, this brutal pandemic took nearly 3.9 lacks lives till the above-mentioned time as reported by WHO. In these circumstances, lockdown process of all socio- economic sectors brought a significant control on viral transmission. Temporal shutdown of all industrial, transport and urban activities significantly helped to reduce pollution load to the environment as well as aquatic ecosystem very effectively. Many countries of South East Asia (Malaysia, Thailand, Indonesia, Bangladesh and Maldives) have been reported their improvement of water quality in various parts (Kundu 2020). In India, nationwide lockdown of 68 days (25 $5^{\text {th }}$ Mach, 2020 to $31^{\text {st }}$ May, 2020) also drastically facilitated to amelioration of environmental quality in most regions of this country. In this period, abrupt decrease of total coliform (TC) load in river Ganga near Kolkata city has been noticed (Mukherjee et al. 2020). It has been also reported that dissolved oxygen (DO) was highly increased in river Ganga near Kolkata city (Dhar et al., 2020). During lockdown, assessment of water quality of river Ganga revealed lowering down of BOD (Biological Oxygen Demand), COD (Chemical Oxygen Demand), fecal coliform (FC), total coliform (TC) and increasing of DO in its water (Dutta et al., 2020). In this period, near about $50 \%$ of heavy metal contamination was reduced in river Ganga (Shukla et al., 2021). Water of Sabarmati River showed improvement of its quality by decreasing suspended particulate matter (SPM) during lockdown (Aman et al., 2020). The river Gomti also improved by its river water quality due to reduction of BOD during lockdown period (Khan et al., 2021).

Despite these significant rivers, Damodar is also very important water source of chhotanagpur plateau region of India. Mineral and coal reserve of upper catchment and fertile soil based lower catchment considerably assist to rapid development of industrial, urban and agricultural activities in its both sides. Heavy metals are being mixed regularly in river water by numerous mining, industries, urban and agricultural sectors. In the past, heavy metal contamination was assessed for some tributaries and main river bed of Damodar by WQI (Water quality Index) method with considering other physiochemical parameters also in it (Singh et al., 2017). Another study of heavy metal contamination of Tamla Nala (important effluent discharge cannel) of river Damodar was carried through different indexing method 
such as Igeo (Geo-accumulation index), PLI (Pollution Load Index) and factor analysis (Banerjee and Gupta, 2013). An additional study has been found on water quality of river Damodar considering various physiochemical and heavy metal parameters and evaluated through factor analysis method (Chatterjee et al., 2009). Recent study on water quality changes during lockdown period in a polluted stretch of river Damodar was conducted considering the physiochemical and heavy metal components and it was assessed by Water Pollution Index (WPI) method (Chakraborty et al., 2020). Before COVID-19 lockdown period, microbial contamination of river Damodar was assessed (Halder et al., 2014; Chatterjee et al., 2009). Pervious researches also indicated that various anthropogenic activities were the main cause of river water deterioration. But there was no such relevant integrated study specially based on heavy metal pollution and microbial load with associated human health risk in any industrially developed catchment of river Damodar. Moreover, there were no published evidence of water quality changes among pre lockdown, during lockdown and unlock period of river Damodar based on heavy metals and microbial load with using advanced GIS techniques. Therefore, the main objectives of this study were (i) to evaluate the changes of heavy metals and microbial load of river water in three period i.e., pre lockdown, during lockdown and unlock (ii) to identify major sources of contaminants and their interrelation using correlation and multivariate analysis and (iii) to assess potential health hazard (non- carcinogenic) of children and adult residence of the catchment area.

\section{Materials and methods}

\subsection{Description of the study area}

River Damodar originates from patland region (Khamarpat hill) of Palamau district under Jharkhand state then flowed to eastern direction and finally joints with river Hooghly. The entire Damodar basin is influenced by monsoonal climate. In summer season, temperature hits up to $47^{\circ} \mathrm{C}$. During winter, temperature falls up to $8.3^{\circ} \mathrm{C}$. Annual average rainfall is recorded as $1200 \mathrm{~mm}$. Monsoonal rainfall is the key source of water supply in Damodar (Singh et al., 2017). The present study area is situated between the transitional zone of chhotanagpur plateau and rarh Bengal. Geographical extension of this study stretch is started from $23^{\circ} 40^{\prime} 50^{\prime \prime} \mathrm{N} / 86^{\circ} 44^{\prime} 49^{\prime \prime} \mathrm{E}$ to $23^{\circ} 40^{\prime} 50^{\prime \prime} \mathrm{N} / 87^{\circ} 18^{\prime} 39^{\prime \prime} \mathrm{E}$ with $65.37 \mathrm{~m}$ length (Fig. 1). Geologically, this area is composed by granitic gneiss and mica schist rocks and inundated by 
Damodar fertile alluvial soil. Naturally, this region is enriched with high quality Gondwana coal reserve and valuable minerals such as iron, copper, limestone etc. This advantage makes this region well developed for establishing any type of mining or metal-based industries and associated urban sectors. Fertile soil and extensive plain land help to grow paddy cultivation in the downward basin of this study area. Many small channels or locally pronounced 'nalla' is drained up to the main riverbed in both side of this section. Solid and liquid untreated wastes from many large and small scale iron industries, steel producing industries, sponge iron plant, cement factories, thermal power plants, chemical factories, municipal garbage and agricultural runoff are directly discharged to riverbed by those nallas and it mixes with main river water.

\subsection{Methods of sample collections}

Confluence points of channels or nallas with main riverbed are considered as most contaminated zone where pollutants directly mixed with fresh water. Therefore, 11 confluence points were selected for collection of samples from main riverbed in this study area. Total $33(11+11+11)$ water samples were collected in three periods. Samples of pre lockdown were collected in December, 2019. Water samples of lockdown were collected after restarting of public transport and experimental laboratories in first week of June, 2020 and again samples of unlock or new normal period were collected in November, 2020. Sample collection and its procedure have been followed by previous study (Chakraborty et al., 2021).

Heavy metals such as zinc $(\mathrm{Zn})$, cadmium $(\mathrm{Cd})$, lead $(\mathrm{Pb})$, nickel $(\mathrm{Ni})$, chromium $(\mathrm{Cr})$ and iron (Fe) were measured by Anodic Stripping Voltammetry (VA797, Switzerland) method in a Hanging Mercury Drop electrode (3M-KCL) using three different pulse analysers (Chakraborty et al., 2020). Peak of voltametric pulse was recorded in a windows computer. Concentration of all heavy metals was expressed in $\mu \mathrm{g} / \mathrm{l}$. Microbial components as Total Viable Count (TVC) was measured by plate count number method. In this technique, bacterial colonies were counted by multiplying plate count number with dilution factor and expressed in cfu/ml (normal saline $0.85 \%$ sterile)(Leong et al., 2018). Total Coliform (TC) and Fecal coliform (FC) bacteria were both estimated by Most Probable Number method (MPN/100mg) and fermentation tubes were prepared for incubation of bacterial growth within 48 hours. After that, Durham tubes were used to test the positive tubes by gas and acid production (Srivastava et al., 2015).

\subsection{Statistical measurement}


202

203

204

205

206

207

208

209

210

211

212

213

214

215

216

217

218

219

220

221

222

223

224

225

226

227

228

229

230

Pearson's correlation coefficient method was used for analysis of interrelationship among heavy metals and microbial parameters. Multivariate analysis such as Hierarchical Cluster Analysis (HCA) was applied for identify possible connection of sources of different parameters contributed to water pollution. Hypothesis testing of significant difference among health hazard index values of ingestion and dermal contact in three periods were conducted by one way ANOVA analysis. All statistical analysis was performed using SPSS (v. 17) and $\mathrm{R}$ studio package for diagrammatic representation.

\subsection{Heavy Metal Pollution Index (HPI)}

Heavy metal pollution index is an integrated approach to study the water quality based on heavy metal contamination and their overall effects in human health (Ahamed et al., 2015; Rezaei et al., 2017). A rating scale of 0 to 1 has been used to assess relative significance of each metal which is oppositely proportional to the standard limit ( $\mathrm{Si}$ ) of respective metal (Reza and Singh, 2010; Prasad and Mondal 2008). HPI was popularly used by many researchers for the assessment of water quality (Abdullah 2013; Setia et al., 2020; Manoj et al., 2012; Ojekunle et al., 2016). Therefore, computation of HPI was conducted step by step as follow:

At first, weightage (Wi) of each metal has been calculated as

$W_{i}=\frac{K}{M A C}$

Where, MAC specifies Maximum Allowable Concentration of respective heavy metals as suggested by Bureau of Indian Standards (BIS 2012)(Table 1). 'K' indicates proportional constant value i.e., 1 .

In the second step, quality rating (Qi) value has been obtained by using formula below:

$Q_{i}=\sum_{i=1}^{n} \frac{M_{i}-I_{i}}{S_{i}-I_{i}} \times 100$

Where, Mi refers the measured value of each metal in water samples. Ii and Si denote the ideal value and standard value of each metal respectively. In this study, Mi and Si of heavy metals were taken from BIS guidelines (Table 1).

At last, calculation of HPI was conducted as follow:

$H P I=\frac{\sum_{i=1}^{n} W_{i} Q_{i}}{\sum_{i=1}^{n} W_{i}}$ 
Where, Wi is weightage of heavy metals (i) and Qi is quality rating of that particular metal, $\mathrm{n}$ indicates total number of heavy metals. The critical value of HPI is considered as 100 and indicated adverse impact on human health (Prasad and Kumari 2008). In this study values of HPI have been classified into three groups as low pollution $(<90)$, medium pollution $(90$ $150)$ and high pollution (> 150)(Kwaya et al., 2019). Spatiotemporal variation of water pollution by HPI has been performed by inverse distance weightage (IDW) interpolation method in Arc GIS 10.4 software.

\subsection{Human health hazard index (HI)}

Human health risk by heavy metal ingestion through drinking water and dermal adsorption were assessed for no carcinogenic type of diseases for children and adults in the study area. Health risk of heavy metal ingestion can be analysed by measuring chronic daily dose intake (CDI) using following formula suggested by USEPA (2011).

$$
C D I_{i}=\frac{C_{w} \times I R \times E F \times E D}{B W \times A T}
$$

Where, $\mathrm{CDI}_{\mathrm{i}}$ is chronic daily dose intake of particular heavy metal $(\mu \mathrm{g} / \mathrm{kg} / \mathrm{day}), \mathrm{C}_{\mathrm{w}}$ is concentration of metal in drinking water $(\mu \mathrm{g} / \mathrm{l})$, IR is ingestion rate of drinking water $(0.701$ for children and 21 for adults), EF is exposure frequency (365 days for both children and adults), ED is exposure duration (6 years for children and 30 years for adults), BW is body weight of persons (15 kg for children and $70 \mathrm{~kg}$ for adults) and AT is average time (2190 days for children and 10,950 days for adults) for non-carcinogenic health risk.

CDI of dermal adsorption was analysed by the prescribed method of USEPA as follow,

$$
C D I_{d}=\frac{C_{w} \times S A \times K_{P} \times E T \times E F \times E D \times C F}{B_{W} \times A T}
$$

Where, $\mathrm{CDI}_{\mathrm{d}}$ is chronic daily dose intake by dermal contact by heavy metals $((\mu \mathrm{g} / \mathrm{kg} / \mathrm{day})$. SA denotes available area of skin contact $\left(\mathrm{cm}^{2}\right) . \mathrm{K}_{\mathrm{p}}$ designates permeability coefficient $\left(\mathrm{cm} /\right.$ hour). ET denotes exposure time (h/day), CF is the conversion factor of unit $\left(\mathrm{L} / \mathrm{cm}^{3}\right)$.

Hazard Quotient (HQ) of each heavy metal was estimated by the ratio of CDI and reference dose of oral intake (RfD) using following formula.

$$
H Q_{\text {(ingestion/dermal) }}=\frac{C D I}{R f D}
$$

$\operatorname{RfD}(\mu \mathrm{g} / \mathrm{kg} / \mathrm{day})$ of each metal was obtained from USEPA guidelines of drinking water quality (Table 1). 
261

262

263

264

265

266

267

268

269

270

271

272

273

274

275

276

277

278

279

280

281

282

283

284

285

286

287

288

289

290

291

292

293

Potential to health risk by all heavy metals of non-carcinogenic type was computed by using following formula.

$$
H I_{(\text {ingestion/dermal) }}=\sum_{i=1}^{n} H Q
$$

Where, HI represents Hazard Index of overall metal ingestion by drinking water. HI value greater than 1 indicates severe possibility to health risk and below than 1 shows no obvious possibility of exposure to health risk (Karunanidhi et al., 2020c; Guerra et al., 2012).

\section{.3. Results}

\subsection{Quality of microbial parameters in river water}

In pre lockdown period, descriptive statistical analysis (Table 1) showed that mean $\pm \mathrm{Sd}$ concentration of TVC, TC and FC was $23545.45 \pm 4156.05,9263.64 \pm 1144.79$ and 2623.64 \pm 889.00 respectively. During lockdown, mean \pm Sd concentration of TVC, TC and FC was $13363.64 \pm 5454.96,4341.82 \pm 728.53$ and $944.27 \pm 134.24$ respectively. Unlock of Covid 19 lockdown, mean $\pm \mathrm{Sd}$ concentration of TVC, TC and FC was found as $15736.36 \pm$ 5468.87, $5856.36 \pm 1013.39$ and $1209.09 \pm 183.44$ respectively. In these three periods, distribution of TVC and FC indicated positive skewness and TC indicated negative skewness. Statistical measurement clearly showed that mean value of TVC, TC and FC was in pre lockdown > unlock > during lockdown period and suggested huge reduction of microbial load during lockdown in river water. Though, $100 \%$ of samples shown excess concentration of microbes than their standard limit in three periods as recommended by World Health Organisation (WHO, 2011) (Table 1).

\subsection{Distribution of heavy metals in pre, during lockdown and unlock period}

Heavy metals of river water in pre lockdown period showed that mean $\pm \mathrm{Sd}$ concentration of Zn was $39845.45 \pm 6280.34$ and Cd was $10.20 \pm 1.77$. Similarly, Pb was $26.18 \pm 5.23$ while $\mathrm{Ni}$ was $84.55 \pm 33.57$. Consequently, $\mathrm{Cr}$ was $87.67 \pm 10.32$ and $\mathrm{Fe}$ was $674.82 \pm 112.96$ (Table 1). Distribution of heavy metals in water samples showed negative skewness of $\mathrm{Zn}$, $\mathrm{Cd}, \mathrm{Ni}, \mathrm{Cr}, \mathrm{Pb}$ and positive distribution of $\mathrm{Fe}$ in this period. All heavy metals of $100 \%$ samples designated higher concentration than their standard limit recommended by BIS (2012). During lockdown, mean $\pm \mathrm{Sd}$ concentration of $\mathrm{Zn}$ was $5300.00 \pm 762.89$ while $\mathrm{Cd}$ was $3.11 \pm 1.33$. $\mathrm{Pb}$ was $3.54 \pm 1.66$ whereas $\mathrm{Ni}$ was $6.55 \pm 1.63$. Similarly, $\mathrm{Cr}$ was $33.86 \pm$ 6.34 and $\mathrm{Fe}$ was $132.91 \pm 8.68$. In this period, distribution of $\mathrm{Zn}, \mathrm{Cd}, \mathrm{Pb}, \mathrm{Cr}$ and $\mathrm{Fe}$ showed negative distribution and only Ni illustrated positive distribution in water samples. During lockdown, zinc concentration of $100 \%$ water samples and $\mathrm{Cd}$ of $63.63 \%$ water samples showed higher concentration than their standard limit. All other heavy metals $(\mathrm{Pb}, \mathrm{Ni}, \mathrm{Cr}$ and 
294

295

296

297

298

299

300

301

302

303

304

305

306

307

308

309

310

311

312

313

314

315

316

317

318

319

320

321

322

323

324

325

326

327

Fe) highlighted no excess concentration in this period due to very low mixing of those metals in water samples. Unlock phase, mean $\pm \mathrm{Sd}$ concentration of $\mathrm{Zn}, \mathrm{Cd}, \mathrm{Ni}, \mathrm{Cr}$ and $\mathrm{Fe}$ was $7566.36 \pm 739.21,5.01 \pm 1.29,5.36 \pm 1.57,22.36 \pm 4.20,41.15 \pm 7.98$ and $284.36 \pm 83.46$ respectively. In this period, $\mathrm{Cd}, \mathrm{Ni}, \mathrm{Cr}$ showed negative skewness and $\mathrm{Zn}, \mathrm{Pb}, \mathrm{Fe}$ stand positive skewness of their distribution. Water samples of unlock period showed Zinc and cadmium exceeded than their standard limit in $100 \%$ sample water. Around $72.72 \%$ and $45.45 \%$ water samples of $\mathrm{Ni}$ and Fe respectively revealed higher concentration than their standard limit. No samples were found excess concentration of $\mathrm{Pb}$ and $\mathrm{Cr}$ in this period. Average concentration of these metals was suggested their same order of accumulation as $\mathrm{Zn}>\mathrm{Fe}>\mathrm{Cr}>\mathrm{Ni}>\mathrm{Pb}>\mathrm{Cd}$ in three periods over river water.

\subsection{Analysis of interrelation between heavy metals and microbes}

Pearson's correlation coefficient of six heavy metals and microbial parameters showed a very strong positive correlation among all heavy metals with each other $(\rho>0.85)$ at 0.05 level of significance (Fig.2a). Before lockdown of Covid-19, water samples showed very high positive correlation between TVC and TC $(\rho=0.92)$. FC conveyed positive correlation with TVC and TC $(\rho=0.83, \rho=0.82$ respectively). Heavy metals like $\mathrm{Cd}, \mathrm{Pb}$ and $\mathrm{Fe}$ indicated significant positive correlation with microbial parameters. During lockdown, very high positive correlation $(\rho>0.80)$ was found among $\mathrm{Zn}, \mathrm{Cd}, \mathrm{Pb}, \mathrm{Ni}$ and $\mathrm{Cr}$ to each other (Fig. 2 b). But Fe showed comparatively low positive correlation with other metals in this period. This indicated common source of origin i.e., industrial discharge of $\mathrm{Zn}, \mathrm{Cd}, \mathrm{Pb}, \mathrm{Ni}$ and $\mathrm{Cr}$ in river water. But, during lockdown Fe might be supplied by natural weathering process of basal rocks. In this period, high positive correlation was identified among microbial. TC and FC brought low positive correlation with $\mathrm{Zn}(\rho=0.59)$ and $\operatorname{Cr}(\rho=0.54)$ respectively. Unlock period, correlation coefficient indicated very low positive correlation $(\rho<0.50)$ of $\mathrm{Zn}$ with Ni, TVC, TC and FC in sample water (Fig. 2c). Ni indicated high positive but not significant relation with other parameters. In this period, microbial parameters suggested strong positive relation with each other $(\rho>0.80)$ but not highly significant relation with other heavy metals in river water. This suggested supply of coliform bacteria from various medical and pathogenic discharge and waste disposal to river bed by many hospitals during COVID 19 situation.

\subsection{Multivariate analysis}

To find out the similarities and dissimilarities among multiple variables or data, hierarchical cluster analysis (HCA) is one of the best methods and selected for water quality analysis in many previous studies (Isa et al., 2017; Muhammad et al., 2016; Panda et al., 2020). It is such 
a unique technique of multivariate analysis which easily defines the distance, difference and connection among the clusters or group of data. In this method, uniformity of clusters and diversity between groups could be easily found out (Fatoba et al., 2017).

In pre lockdown, during lockdown and unlock period, dendogram of cluster analysis showed that there were three cluster of microbial and heavy metal parameters (Fig.3 a, b, c). In both three periods, cluster I consists of $\mathrm{Cd}, \mathrm{Pb}, \mathrm{Ni}, \mathrm{Cr}, \mathrm{Fe}$ and $\mathrm{FC}$ indicated high similarity among these parameters and most possibly common source of discharge i.e., industrial wastes. IN pre lockdown, Cluster II was contributed by TC and cluster III was comprised of Zn and TVC indicated high possibility of TVC enrichment by zinc supply from agricultural or industrial source. During lockdown and unlock period, cluster II was comprised of Zn, TC and cluster III was consisted of TVC.

\subsection{Assessment of Heavy Metal Pollution Index (HPI)}

In the study stretch of river Damodar, HPI of pre lockdown showed that around $100 \%$ water samples $(\mathrm{n}=11)$ were highly polluted by heavy metal contamination (Table 2$)$. During lockdown, around 54.54\% water samples low pollution and $45.45 \%$ samples indicated medium pollution. In this period, no sample was detected as highly polluted and clearly showed betterment of river water quality. Unlock phase, 9.09\% samples were lowly polluted, around $45.45 \%$ indicated medium polluted and rest $45.45 \%$ indicated highly polluted water. This outcome exposed again increase of contamination of heavy metals and their pollution in river water. Spatial mapping showed that the lower course of river water was more polluted by heavy metals in three periods (Fig 4).

\subsection{Analysis of human health hazard of three periods}

Heavy metal can affect human body via exposure pathways as ingestion of drinking water, food, inhalation or dermal contact (Somoano et al., 2009). In the present study, expected non carcinogenic health risk of children and adult population was assessed for ingestion and dermal adsorption of river water.

In pre lockdown period, mean HQ value of six heavy metal ingestion by children was found as an order of $\mathrm{Zn}>\mathrm{Cd}, \mathrm{Cr}>\mathrm{Pb}>\mathrm{Ni}>\mathrm{Fe}$ by their mean value (Table 3). During lockdown, mean $\mathrm{HQ}$ values of six heavy metals were arranged as $\mathrm{Zn}>\mathrm{Cr}>\mathrm{Cd}>\mathrm{Pb}>\mathrm{Ni}>\mathrm{Fe}$. Unlock phase, mean HQ values showed as same as lockdown period i.e., $\mathrm{Zn}>\mathrm{Cr}>\mathrm{Cd}>\mathrm{Pb}>\mathrm{Ni}>$ Fe. In these three periods, Zn posed highest possibility of health risk (HQ > 1) via drinking 
water for children by its mean value. Mean HQ of heavy metal ingestion by adults in pre lockdown, during lockdown and unlock period showed their order as $\mathrm{Zn}>\mathrm{Cr}>\mathrm{Cd}>\mathrm{Pb}>\mathrm{Ni}$ $>\mathrm{Fe}$ and indicated $\mathrm{Zn}$ as highest possibility to health risk for adults like children. Total health risk of all six heavy metals ingestion by children showed that its cumulative hazard index (HI) value was ranged from 7.82 to 11.95 with mean value of 10.04 in pre lockdown period (Fig. 5a). During lockdown, HI showed the ranges from 1.20 to 2.26 with 1.78 mean value. Unlock phase, HI value was ranged from 2.00 to 3.10 with 2.53 mean values. In these all three periods, HI values of ingestion of heavy metals by children indicated that $100 \%$ water samples were higher than 1 , which suggested higher possibility of non-carcinogenic health risk for them.

Total HI of ingestion of drinking water by adult population showed the ranges in pre lockdown was 4.61 to 7.00 with 5.90 mean values (Fig 5a). During lockdown, Total HI was ranged from 0.74 to 1.38 with 1.09 mean score. Unlock period, HI value was ranged from 1.22 to 1.90 with 1.55 mean values. In pre lockdown and unlock period, $100 \%$ samples showed HI value > 1. During lockdown, 36.36\% sample showed HI < 1 , and indicated betterment of water quality in those sample sites.

Heavy metals intake due to dermal adsorption like bathing or recreational contact of river water by children in pre lockdown showed that their mean value were in an order of $\mathrm{Zn}>\mathrm{Pb}$ $>\mathrm{Cr}>\mathrm{Cd}>\mathrm{Fe}>\mathrm{Ni}$ (Table 3). During lockdown, their mean value showed $\mathrm{Cr}>\mathrm{Zn}>\mathrm{Pb}>$ $\mathrm{Cd}>\mathrm{Fe}>\mathrm{Ni}$ by their order of accumulation. Unlock period, mean HQ of heavy metals ordered as $\mathrm{Cr}>\mathrm{Pb}>\mathrm{Zn}>\mathrm{Cd}>\mathrm{Fe}>\mathrm{Ni}$. Dermal HQ of heavy metals for adults in pre lockdown showed that $\mathrm{Zn}$ has highest mean value for health risk during lockdown and unlock, Cr indicated highest mean HQ for health risk for them.

Total HI value of dermal adsorption by children in pre lockdown was obtained its ranges 4.58E-02 to 7.07E-02 with 6.00E-02 mean value (Fig. 5b). Total HI of during lockdown was ranged from $8.12 \mathrm{E}-03$ to $1.67 \mathrm{E}-02$ with $1.27 \mathrm{E}-02$ mean value. Unlock period, HI showed its ranges from $1.27 \mathrm{E}-02$ to $2.23 \mathrm{E}-02$ with $1.75 \mathrm{E}-02$ mean value. HI value of dermal contact of adult persons in pre lockdown showed that its ranges from $2.68 \mathrm{E}-02$ to $4.13 \mathrm{E}-02$ with $3.51 \mathrm{E}-$ 02 mean. During lockdown, it ranged from 4.75E-03 to 9.75E-03 with 7.42E-03 mean value (Fig 5b). Unlock period, HI was ranged from 7.39E-03 to $1.30 \mathrm{E}-02$ with $1.02 \mathrm{E}-02$ mean value. All samples of pre lockdown, during lockdown and unlock period (100\%) showed total HI value lower than 1 and indicated very negligible health risk to children and adults by dermal contact in this region. 


\subsection{Analysis of Variance (ANOVA)}

When difference between or within variables are compared for three or more groups, then one -way ANOVA testing is appropriate to use. In this analysis, if ' $F$ ' value observed greater than level of significance $(\rho)$ value then null hypothesis is rejected and significant difference among groups is considered. In this study, one way ANOVA test was conducted for analysis of difference among HI values of pre lockdown, during lockdown and unlock period for ingestion and dermal contact by children and adults. Means of HI (ingestion, dermal) values of three periods were compared by least square difference (LSD) method at 0.05 significance level. Analysis showed that all F value was much greater than their significant level $(\rho=$ 0.000 ) and hence completely accepted significant changes in mean HI values of three periods for adults and children (Table 4).

\section{Discussion}

The significant and sudden fall in bacterial load during lockdown period was observed in the river water of the present study stretch. Many researches on water quality changes during lockdown were identified and the main cause of decrease in microbial population i.e., temporary shutdown of industries, traffic vehicles, recreational amusements, bathing etc near river bank has been recognised (Yunus et al., 2020; Khan et al., 2021; Selvam et al., 2020b; Mukherjee et al., 2020; Dutta et al., 2020). Another cause may be usage of disinfecting sanitizers and its mixing with river water due to maintain of COVID-19 safety measures. Again, amplification of microbes after reopening of industrial and all other economic activities indicated untreated waste water and recreational activities are the main sources of their concentration. On the assessment of heavy metals, it was clearly observed that $100 \%$ sample water was over contaminated by heavy metals than their standard value recommended by WHO. Higher concentration of $\mathrm{Zn}$. Fe, $\mathrm{Pb}$ and $\mathrm{Ni}$ indicated industrial discharge of these metals by iron and steel, chemical industries, coal mining extracts, agricultural runoff in this period. During lockdown, concentration of $\mathrm{Pb}, \mathrm{Ni}, \mathrm{Cr}$ and $\mathrm{Fe}$ was lowered down than standard value in all samples. Other study on heavy metals in drinking water at COVID-19 lockdown times also revealed huge reduction of toxic metals load in water resource (Selvam et al., 2020b; Shukla et al., 2021; Chakraborty et al., 2021). Very high positive correlation among those heavy metals and microbial signified that they mixed with river water from possibly common sources i.e., industrial wastes, agricultural runoff or municipal garbage. During lockdown, shutdown of industrial activities and generation of waste materials helped to reduce their load in river water. It is most important part of our analysis that significant positive changes brought in river water quality by Heavy Metal Pollution Index (HPI). 
During lockdown, around 54.54\% water samples were transformed into low pollution and around $45.45 \%$ samples transformed into medium pollution. This is a significant symptom of river water quality improvement. Assessment of non-carcinogenic health risk by heavy metals showed that HQ (ingestion) of Zinc has higher potentiality to health risk among all metals to children and adult both. Hazard Index (HI) value indicated that children are more potential to health risk than adult population in the study area. Though, during lockdown HI values of ingestion of drinking water by children and adult were lowered down than pre lockdown and unlock, but there were higher possibilities to health risk remain same (HI > 1). HI values of dermal contact suggested that there were no immediate possibilities of health risk to children and adult in this region. In the present study, trend of increasing microbial and heavy metal pollution load after reopening of all industrial, traffic, recreational sectors in unlock period strongly recommended that immediate scientific management practice should be adopted to sustain river water quality for its ecosystem and human health. Therefore, industrial authorities should be followed the environmental norms and regulation before direct discharge of waste materials to riverbed. Municipal corporations should specify the definite places to deposition of domestic wastes. Not only that, purification plant of river water should be installed near river bank. In city areas, more usages of personal RO (reverse osmosis) purification machines will be encouraged by local authorities. Higher usages of chemical fertilisers and pesticides must be controlled. Most of all, village level public awareness programme will effectively be helped to reduce pollution contamination on river water.

\section{Conclusion}

The physical, chemical and microbial properties of water of river Damodar has been evaluated by many researchers. Still, there was no integrated study particularly on heavy metals pollution and microbial load of river Damodar. Consequently, there was no study which was conducted on human health risk related water quality assessment. Moreover, there was no assessment of river water quality changes in pre, during lockdown and unlock period of COVID -19 situation. Therefore, this study was performed on the basis of microbial load (TVC, TC, FC), heavy metals load ( $\mathrm{Zn}, \mathrm{Cd}, \mathrm{Pb}, \mathrm{Ni}, \mathrm{Cr}, \mathrm{Fe}$ ) and related non carcinogenic health risk of human body in three different situations i.e., normal (pre lockdown), during lockdown and new normal (unlock) phase. The study showed that TVC, TC and FC were above their standard limit of concentration in three periods. There was noticeable decrease in microbial load in river water during lockdown. Mean concentration of heavy metals showed 
$\mathrm{Zn}>\mathrm{Fe}>\mathrm{Cr}>\mathrm{Ni}>\mathrm{Pb}>\mathrm{Cd}$ over three period in river water. Zink, Iron, lead and nickel have been found abandoned in pre lockdown period. Heavy metal pollution index (HPI) indicated that $100 \%$ sample was highly polluted in pre lockdown which changed to $54.54 \%$ sample of low polluted and $45.45 \%$ sample of medium polluted during lockdown. Again $45.45 \%$ sample water changed to high pollution after restarting of industries, traffic and recreational activities. GIS mapping showed that lower stretch of this river was highly polluted in three periods than upper stretch. Hazard Index showed that children were much prone to noncarcinogenic health risk than adult in this region. HI of ingestion indicated $>1$ for children in all samples of three periods and confirms possibilities to health hazard by ingestion of this polluted water. HI of dermal contact showed that there were no possibilities to health-related hazard for any samples of children or adult in this area. Restart of all economic activities and again deterioration of water quality could be solved by scientific remediation and management practice by planners, entrepreneurs and mass public in this catchment area. There is enormous possibility to do further study in these changing circumstances and simultaneously it is highly required to find out the solutions because this river contributes multidimensional ecosystem services to millions of people in India. This field based scientific study will assist to policy makers for sustainable management of river health.

\section{Acknowledgements}

The authors show their kind acknowledgment to the Dept. of Geography and Microbiology, Raja N. L. Khan Women's College (Autonomous), Department of Geology \& Geophysics, Indian Institute of Technology (IIT), Kharagpur, West Bengal, India for their laboratory facilities and kind encouragement.

\section{Author contributions}

P.K.Shit - conceptualized and planned the study and reviewed and edited the manuscript. B. Chakraborty - conducted the survey, water sampling, analyzed the data, and interpreted the results. S.Roy -conducted the survey, water sampling, prepared the maps. S. Saha. -conducted the survey, prepared the graphs, and analyzed the data. S. Bhattacharjee- reviewed and edited the manuscript. P.P.Adhikary - reviewed and edited the manuscript. B.Bera - supervised the study and reviewed and 
495

496

497

498

499

500

501

502

503

504

505

506

507

508

509

510

511

512

513

514

515

516

517

518

519

520

521

522

523

edited the manuscript. D. Sengupta -supervised the overall research, interpreted the results. All authors have read and approved the final manuscript.

\section{Funding}

This research was supported by the Department of Geography, Raja N. L. Khan Women's College (Autonomous), affiliated to Vidyasagar University, Midnapore, West Bengal, India. The author (P. K. Shit) grateful acknowledges West Bengal DSTBT for financial support through R\&D Research Project Memo no. 104(Sanc.)/ST/P/S\&T/ 10G-5/2018).

\section{Ethic declarations}

\section{Competing interests}

The authors declare that they have no competing interests.

\section{Ethics approval and consent to participate}

Not applicable

\section{Consent for publication}

Not applicable

\section{Data availability}

The datasets used and analyzed during the current study are available from the corresponding author on reasonable request.

\section{References}

AbdullahEJ (2013) Evaluation of surface water quality indices for heavy metals ofDiyala River-Iraq. J. Nat. Sci. Res. 3, 6369.

AhmedMK, Shaheen N, Islam MS, Habibullah-al-Mamun M, Islam S,Mohiduzzaman M, Bhattacharjee L (2015) Dietary intake of trace elements fromhighly consumed cultured fish (Labeorohita, Pangasius and Oreochromismossambicus) and human health risk implications in Bangladesh. Chemosphere 128,284-292. https://doi.org/10.1016/j.chemosphere.2015.02.016.

Akhilesh J, Savita D, Suman M (2009) Some trace elements investigation in groundwater of Bhopal and Sehore District in Madhya Pradesh, India. J Appl Sci Environ Manag 13(4):47-50.

AliH, KhanE(2018) What are heavy metals? long-standing controversy over thescientific use of the term 'heavymetals'proposal of a comprehensive definition.Toxicol. Environ. Chem. 100, 6e19. 
Aman MA, Salman MS, Ali PY (2020) COVID-19 and its impact on environment:Improved pollution levels during the lockdown period-a case from Ahmedabad,India. Remote Sens. Appl.: Soc. Environ., 100382 https://doi.org/10.1016/j.rsase.2020.100382.

Banerjee US, Gupta S (2013) Impact of Industrial Waste Effluents On River Damodar Adjacent To Durgapur Industrial Complex, West Bengal, India. Environ Monit. Assess. DOI 10.1007/S10661-012-2690-1

Besharati S, Motamedi H, Zallaghi R (2018) A survey on microbial quality and antibiotic resistance in Karoon River, Khuzestan, Iran Applied Water Science (2018) 8:146 https://doi.org/10.1007/s13201-018-0786-7

BIS (Bureau of Indian Standards) (2012) Indian Standard, Drinking Water-Specification, Second Revision, IS 10500: ICS 13.060.20

Chakraborty B, Roy S, Bera A, Adhikary PP, Bera B, Sengupta D, Bhunia GS, Shit PK (2021a) Cleaning the river Damodar (India): impact of COVID-19 lockdown on water quality and future rejuvenation strategies.Environment,DevelopmentandSustainability.https://doi.org/10.1007/s10668-020-01152-8

ChakrabortyB, Roy S, Bera A, Adhikary PP, Bera B, Sengupta D, Bhunia GS, Shit PK (2021b) Eco-restoration of river water quality during COVID-19 lockdown in the industrial belt of eastern India. Environ. Sci and Pollution Research.https://doi.org/10.1007/s11356-021-12461-4

Chatterjee SK, Bhattacharjee I, Chandra G (2010) Water Quality Assessment Near An Industrial Site Of Damodar River, India. Environ Monit Assess. Https://Doi.Org/ 10.1007/S10661-008-0736-1.

Dhar I, Biswas S, Mitra A, Pramanick P, Mitra A (2020) COVID-19 Lockdown Phase: A Boon For The River Ganga Water Quality Along The City Of Kolkata. NUJS J. Regulatory Studies, 2456-4605(O).

Di’az-Somoano M, Kylander ME, Lo'pez-Anto'n MA, Suárez-Ruiz I,Marti’nez-Tarazona MR, Ferrat M, Kober B, Weiss DJ (2009) Stable lead isotope compositions in selected coals from around the world and implications for present day aerosol source tracing, Environ. Sci. Technol. 43: 1078-1085.

Dutta V, Dubey D, Kumar S (2020) Cleaning the River Ganga: impact of lockdown onwater quality and future implications on river rejuvenation strategies. Sci. TotalEnviron., 140756 https://doi.org/10.1016/j.scitotenv.2020.140756.

Fatoba JO, Sanuade OA, Hammed OS, Igboama WW (2017) The use ofmultivariate statistical analysis in the assessment of groundwater hydrochemistry insome parts of southwestern Nigeria. Arab. J. Geosci. 10 (15) https://doi.org/10.1007/s12517-017-3125-7.

Giuliano V, Pagnanelli F, Bornoroni L, Toro L (2007) Toxic elements at a disused mine district: particle size distribution and total concentration in stream sediments and mine tailings. J Hazard Mater 148(1-2):409.

Guerra F, TrevizamAR, Muraoka T, Marcante NC, Canniatti-Brazaca SG (2012) Heavy metals in vegetables and potential risk for human health, Sci. Agric. 69: 54-60.

Hakan P (2006) The distribution and sources of heavy metals in Izmit Bay surface sediment affected by a polluted stream. Mar Pollut Bull 52:1197-1206.

Haldar D, Halder S, Das P, Halder G (2014) Assessment of water quality of Damodar River in South Bengal region ofIndia by Canadian Council of Ministers of Environment (CCME) WaterQuality Index: a case study. Desalination and Water Treatment, 1-14. doi: 10.1080/19443994.2014.987168

IsaNM, Aris AZ, SheikhyNarany T, Sulaiman WNA (2017)Applying the scores ofmultivariate statistical analyses to characterize the relationships between thehydrochemical properties and groundwater conditions in respect of the monsoonvariation in Kapas Island, Terengganu, Malaysia. Environ. Earth Sci. 76 (4) https://doi.org/10.1007/s12665-017-6487-y. 
JohnV, JainP, Rahate M, Labhasetwar P (2014) Assessment of deterioration in water quality from source to household storage insemi-urban settings of developing countries. Environ. Monit. Assess. 186, 725 734.

Leong SS, Ismail J, Denil NA, Sarbini SR, Wasli W, Debbie A (2018) Microbiological and Physicochemical Water Quality Assessments of River Water in an Industrial Region of the Northwest Coast of Borneo. Water 10 doi: 10.3390/w10111648

Karunanidhi D, Aravinthasamy P, Subramani T, Muthusankar G (2020) Revealingdrinking water quality issues and possible health risks based on water quality index(WQI) method in the Shanmuganadhi River basin of South India. Environ GeochemHlth. https://doi.org/10.1007/s1065 3-020-00613 -3.

Karunanidhi D, AravinthasamyP, Kumar D, SubramaniT, Roy PD, (2020c) Sobolsensitivity approach for the appraisal of geomedical health risks associated with oralintake and dermal pathways of groundwater fluoride in a semi-arid region of southIndia. Ecotoxicol. Environ. Saf 194 (110438). https://doi.org/10.1016/j.ecoenv.2020.110438.

Kavcar P, Sofuoglu A, Sofuoglu SC (2009) A health risk assessment for exposure to trace metals via drinking water ingestion pathway, Int. J. Hyg. Environ. Health 212: 216-227.

Khan R, Saxena A, Shukla S, Selvam S, Goel P (2021) Effect of COVID-19 lockdownon the water quality index of River Gomti, India, with potential hazard of faecal-oraltransmission. Environ. Sci. Pollut. Res.https://doi.org/10.1007/s11356-021-13096-1.

Klavins M, Briede A, Rodinov V, Kokorite I, Parele E, Klavina I (2000) Heavy metals in Rivers of Latvia. Sci Total Environ 262:175-183.

Kundu C (2020) Has the Covid-19 lockdown returned dolphins and swans to Italian waterways? The India Today, 22 March 2020. 〈https://www.indiatoday.in/fact-check/story/has-covid19-lockdown-returned-dolphins-swans-italianwaterways 165845 7-2020-03-22〉. (Accessed 14 April 2020).

Kwaya MY, HamiduH, Mohammed AI, Abdulmumini YN, Adamu IH, Grema HM, Dauda M, Halilu FB, Kana AM (2019) Heavy metals pollution indices andmultivariate statistical evaluation of groundwater quality of Maru Town andEnvirons. J. Mat. Environ. Sci. 10, 32-44.

Manoj K, Kumar Padhy P, ChaudhuryS (2012) Study of heavy metal contamination ofthe river water through index analysis approach and environmetrics. Bull. Environ.Pharmacol. Life Sci. 1, 7-15.

Mohammadi AA, Zarei A, Majidi S, Ghaderpoury A, Hashempour Y, Saghi MH, Alinejad A, Yousefi M, Hosseingholizadeh N, Ghaderpoori M (2019) Carcinogenic and non-carcinogenic health risk assessment of heavy metals in drinking water of Khorramabad, Iran. MethodsX 6 :1642-1651.https://doi.org/10.1016/j.mex.2019.07.017

MuhammadI, AshiruS, IbrahimID, SalawuK, MuhammadDT, MuhammadNA (2014) Determination of some heavy metals in wastewater and sediment ofartisanal gold local mining site of Abare Area in Nigeria. J. Environ. Treat. Technol.1 (3), 174-182.

Mukherjee P, Pramanick P, Zaman S, Mitra A (2020) Eco- Restoration Of River Ganga Water Quality During COVID-19 Lockdown Period Using Total Coliform (TC) As Proxy.NUJS J. Regulatory Studies, 24564605(O).

Ojekunle OZ, Ojekunle OV, Adeyemi AA, Taiwo AG, Sangowusi OR, Taiwo AM, Adekitan AA (2016) Evaluation of surface water qualityindices and ecological risk assessment for heavymetals in scrap yard neighbourhood. SpringerPlus 5:560. DOI 10.1186/s40064-016-2158-9.

PandaB, Chidambaram S, Thilagavathi R, et al., (2020) Source governed trace metalanomalies in groundwater of foothill aquifer and its health effect. Appl. Water Sci.10, 173. https://doi.org/10.1007/s13201-020-01253-9.

Prasad B, Kumari S (2008) Heavy metal pollution index of ground water of anabandoned open cast mine filled with fly ash: a case study. Mine Water Environ. 27:(4), 265-267.

Prasad B, Mondal KK (2008) The impact of filling an abandoned open cast mine with fly ash on ground water quality: a case study. Mine Water Environ 27(1):40-45 
Rahube TO, Yost CK (2010) Antibiotic resistance plasmids in wastewatertreatment plants and their possible dissemination into the environment. Afr J Biotech 9:9183-9190.

Rezaei A, Hassani H, Hayati M, Jabbari N, Barzegar R (2017) Risk assessment andranking of heavy metals concentration in Iran's Rayen groundwater basin usinglinear assignment method. Stoch. Environ. Res. Risk Assess. 32 (5), 13171336.https://doi.org/10.1007/s00477-017-1477-x.

Reza R, Singh G (2010) Heavy metal contamination and its indexing approach for river water. Int J Environ Sci Tech 7(4):785-792

Sekar KG, Suriyakala K (2016) Seasonal variation of heavy metal contamination of groundwater in and around Udaiyarpalyam Taluk, Ariyalur district, Tamil Nadu.World Sci. News 47-60.

Selvam S, Muthukumar P, Venkatramanan S, Roy PD, Manikanda Bharath K,Jesuraja K (2020a) SARS-CoV-2 pandemic lockdown: effects on air quality in theindustrialized Gujarat state of India. Sci. Total Environ., 140391 https://doi.org/10.1016/j.scitotenv.2020.140391.

Selvam S, Jesuraja K, Venkatramanan S, Chung SY, Roy PD, Muthukumar P,Kumar M (2020b) Imprints of pandemic lockdown on subsurface water quality in thecoastal industrial city of Tuticorin, south India: a revival perspective. Sci. TotalEnviron., 139848 https://doi.org/10.1016/j.scitotenv.2020.139848.

Setia R, Dhaliwal SS, Kumar V, Singh R, Kukal SS, Pateriya B (2020) Impactassessment of metal contamination in surface water of Sutlej River (India) on humanhealth risks. Environ. Pollut., 114907 https://doi.org/10.1016/i.envpol.2020.114907.

Shukla T, Sen IS, Boral S, Sharma S (2021) A Time-Series Record during COVID-19Lockdown Shows the High Resilience of Dissolved Heavy Metals in the Ganga River.ACS Publications Collection.https://doi.org/10.1021/acs.estlett.0c00982.

Singh RK, Chaturvedi A, Kumari K (2017) Water-quality assessment of Damodar River and its tributariesand subtributaries in Dhanbad Coal mining areas of India basedon WQI. Sustain. Water Resour. Manag.DOI 10.1007/s40899-017-0159-7

Srivastava S, Dash H R, Das S (2017) Assessment of the Biological Quality of Riverine Water Using Pathogenicity Islands (PAIs) of Coliform Bacteria as Pollution Indicator1. Water Resources 44(1): 150157. DOI: $10.1134 / \mathrm{S} 0097807817010146$

Sun F, Chen J, Tong Q, Zeng S (2007) Integrated risk assessment and screening analysis of drinking water safety of a conventional water supply system, Water Sci. Technol. 56: 47-56.

Tam NFY, Wong WS (2000) Spatial variation of heavy metals in surface sediments of Hong Kong mangrove swamps. Environ Pollut 110:195-205.

TiwariAK, Maio MD, Singh PK, Mahato MK (2015) Evaluation of surface water quality by using GIS and a heavy metal pollution index (HPI) model in a coal mining area, India. Bull. Environ. Contam. Toxicol. 95, 304e310.

Tumuklu A, Yalcin MG, Sonmez M (2007) Detection of heavy metal concentrations in soil caused by Nidge City Garbage Dump. Pol J Environ Stud 16(4):651.

USEPA (1989), Risk Assessment Guideline for Superfund V. 1 Human Health Evaluation Manual (Part A).U.S. Environmental ProtectionAgency,https://doi.org/EPA/540/1-89/002.

USEPA (1995) EPA-823-B-94-005a, b Water Quality Standards Handbook, 2nd ed.... National Technical Information Service, Springfield, VA.

USEPA (2011) Exposure Factors Handbook, 2011 edn.,. U.S. Environmental ProtectionAgency, https://doi.org/EPA/600/R090/052F.

Wu Z, Zhang D, Cai Y, Wang X, Zhang L, Chen Y (2017) Water quality assessment basedon the water quality index methodin Lake Poyang: The largestfreshwater lake in China. Scientific Reports.7:17999| DOI:10.1038/s41598017-18285-y.

Yahaya MI, Mohammad S, Abdullahi BK (2009) Seasonal variations of heavy metals concentration in Abbatoir dumping site in Nigeria. J Appl Sci Environ Manag 13(4):9-13. 
705

706

707

708

709

710

711

712

713

714

715

716

717

718
Yunus AP, MasagoY, Hijioka Y (2020) COVID-19 and surface water quality:improved lake water quality during the lockdown. Sci. Total Environ., 139012https://doi.org/10.1016/j.scitotenv.2020.139012.

ZouL, Xia J,SheD (2018) Analysis of impacts of climate change and human activities on hydrological drought: A case study in theWei River Basin, China. Water Resour. Manag. 32, 1421-1438. 
Table 1: Statistical description of heavy metals and microbial components in river water

\begin{tabular}{|c|c|c|c|c|c|c|c|c|c|c|c|}
\hline & & $\mathrm{Zn} 2+$ & $\mathrm{Cd} 2+$ & $\mathrm{Pb} 2+$ & $\mathrm{Ni2}+$ & $\mathrm{Cr}$ & $\mathrm{Fe}$ & & TVC & $\mathrm{TC}$ & FC \\
\hline $\begin{array}{c}\text { Standard } \\
\text { value }(\mu \mathrm{m} / \mathrm{l}) \\
(\mathrm{BIS}, 2012) \\
\end{array}$ & & 15000 & 3 & 10 & 20 & 50 & 300 & $\begin{array}{l}\text { Standard value } \\
\text { (WHO, 2011) }\end{array}$ & $100 \mathrm{cfu} \mathrm{ml}^{-1}$ & $30 \mathrm{coli} / \mathrm{ml}$ & 0 coli $/ \mathrm{ml}$ \\
\hline $\begin{array}{c}\text { Ideal value } \\
(\mu \mathrm{m} / \mathrm{l})(\mathrm{BIS}, \\
2012)\end{array}$ & & 5000 & 0 & 0 & 0 & 0 & 0 & $\begin{array}{c}\text { Ideal value } \\
\text { (WHO, 2011) }\end{array}$ & - & - & - \\
\hline $\begin{array}{c}\text { RfD } \\
\text { (USEPA } \\
2011 \text { ) } \\
\end{array}$ & & 300 & 0.5 & 1.4 & 20 & 3 & 700 & & & & \\
\hline \multirow{7}{*}{$\begin{array}{c}\text { Pre } \\
\text { lockdown }\end{array}$} & Mean & 39845.45 & 10.20 & 26.18 & 84.55 & 87.67 & 674.82 & Mean & 23545.45 & 9263.64 & 2623.64 \\
\hline & $\begin{array}{l}\text { Standard } \\
\text { Error }\end{array}$ & 1893.60 & 0.54 & 1.58 & 10.12 & 3.11 & 34.06 & Standard Error & 1253.10 & 345.17 & 268.04 \\
\hline & $\begin{array}{c}\text { Standard } \\
\text { Deviation }\end{array}$ & 6280.34 & 1.77 & 5.23 & 33.57 & 10.32 & 112.96 & $\begin{array}{l}\text { Standard } \\
\text { Deviation }\end{array}$ & 4156.05 & 1144.79 & 889.00 \\
\hline & $\begin{array}{l}\text { Sample } \\
\text { Variance }\end{array}$ & 39442727.27 & 3.15 & 27.36 & 1127.27 & 106.51 & 12759.56 & Sample Variance & 17272727.27 & 1310545.45 & 790325.45 \\
\hline & Kurtosis & -2.18 & -1.08 & -1.24 & -1.42 & -1.27 & -2.27 & Kurtosis & -0.56 & -0.61 & -1.27 \\
\hline & Skewness & -0.10 & -0.34 & -0.33 & -0.04 & -0.48 & 0.10 & Skewness & 0.25 & -0.48 & 0.63 \\
\hline & Range & 15000.00 & 5.20 & 15.00 & 90.00 & 28.22 & 258.00 & Range & 13000.00 & 3600.00 & 2460.00 \\
\hline \multirow{7}{*}{$\begin{array}{l}\text { During } \\
\text { lockdown }\end{array}$} & Mean & 5300.00 & 3.11 & 3.54 & 6.55 & 33.86 & 132.91 & Mean & 13363.64 & 4341.82 & 944.27 \\
\hline & $\begin{array}{l}\text { Standard } \\
\text { Error }\end{array}$ & 230.02 & 0.40 & 0.50 & 0.49 & 1.91 & 2.62 & Standard Error & 1644.73 & 235.94 & 40.48 \\
\hline & $\begin{array}{l}\text { Standard } \\
\text { Deviation }\end{array}$ & 762.89 & 1.33 & 1.66 & 1.63 & 6.34 & 8.68 & $\begin{array}{l}\text { Standard } \\
\text { Deviation }\end{array}$ & 5454.96 & 782.53 & 134.24 \\
\hline & $\begin{array}{l}\text { Sample } \\
\text { Variance }\end{array}$ & 582000.00 & 1.77 & 2.76 & 2.67 & 40.14 & 75.29 & Sample Variance & 29756545.45 & 612356.36 & 18020.82 \\
\hline & Kurtosis & -0.75 & -1.53 & -1.51 & -0.81 & -1.94 & 3.67 & Kurtosis & -0.69 & 0.21 & -0.56 \\
\hline & Skewness & -0.10 & -0.45 & -0.23 & 0.24 & -0.61 & -1.75 & Skewness & 0.59 & -0.55 & 0.17 \\
\hline & Range & 2400.00 & 3.23 & 4.70 & 5.00 & 13.99 & 30.00 & Range & 16200.00 & 2600.00 & 440.00 \\
\hline \multirow{7}{*}{$\begin{array}{l}\text { Unlock } \\
\text { phase }\end{array}$} & Mean & 7566.36 & 5.01 & 5.36 & 22.36 & 41.15 & 284.36 & Mean & 14463.64 & 5856.36 & 1209.09 \\
\hline & $\begin{array}{l}\text { Standard } \\
\text { Error }\end{array}$ & 222.88 & 0.39 & 0.47 & 1.27 & 2.41 & 25.16 & Standard Error & 2454.84 & 305.55 & 55.31 \\
\hline & $\begin{array}{c}\text { Standard } \\
\text { Deviation }\end{array}$ & 739.21 & 1.29 & 1.57 & 4.20 & 7.98 & 83.46 & $\begin{array}{l}\text { Standard } \\
\text { Deviation }\end{array}$ & 8141.78 & 1013.39 & 183.44 \\
\hline & $\begin{array}{l}\text { Sample } \\
\text { Variance }\end{array}$ & 546425.45 & 1.65 & 2.45 & 17.65 & 63.68 & 6965.65 & Sample Variance & 66288545.45 & 1026965.45 & 33649.09 \\
\hline & Kurtosis & -0.09 & -1.56 & -0.98 & -0.59 & -1.83 & -1.77 & Kurtosis & -0.46 & -0.10 & -0.04 \\
\hline & Skewness & 1.08 & -0.16 & 0.21 & -0.12 & -0.47 & 0.00 & Skewness & -0.51 & -0.36 & 0.26 \\
\hline & Range & 2000.00 & 3.24 & 5.00 & 14.00 & 19.55 & 228.00 & Range & 25100.00 & 3140.00 & 610.00 \\
\hline
\end{tabular}


Table 2: Quality of sample water samples in three period by HPI method.

\begin{tabular}{llll}
\hline HPI Category & Pre lockdown & During lockdown & Unlock phase \\
\hline Low pollution $(<90)$ & $0 \%$ & $54.54 \%$ & $9.09 \%$ \\
Medium pollution $(90-150)$ & $0 \%$ & $45.45 \%$ & $45.45 \%$ \\
High pollution $(>150)$ & $100 \%$ & $0 \%$ & $45.45 \%$ \\
\hline
\end{tabular}

Table 3: Hazard quotient (HQ) values of six heavy metals for ingestion and Dermal

\begin{tabular}{|c|c|c|c|c|c|c|c|c|}
\hline Category & period & Statistics & Zn2+ & $\mathrm{Cd} 2+$ & $\mathrm{Pb} 2+$ & $\mathrm{Cr}+$ & Ni2+ & $\mathrm{Fe}$ \\
\hline \multirow{9}{*}{$\begin{array}{c}\text { HQ } \\
\text { Ingestion } \\
\text { (Children) }\end{array}$} & \multirow{3}{*}{$\begin{array}{c}\text { Pre } \\
\text { lockdown }\end{array}$} & Mean & 6.20 & 1.36 & 0.87 & 1.36 & 0.20 & 0.04 \\
\hline & & Minimum & 4.98 & 1.00 & 0.60 & 1.11 & 0.09 & 0.04 \\
\hline & & Maximum & 7.31 & 1.69 & 1.10 & 1.55 & 0.30 & 0.05 \\
\hline & \multirow{3}{*}{$\begin{array}{c}\text { During } \\
\text { lockdown }\end{array}$} & Mean & 0.82 & 0.29 & 0.12 & 0.53 & 0.02 & 0.01 \\
\hline & & Minimum & 0.62 & 0.11 & 0.04 & 0.40 & 0.01 & 0.01 \\
\hline & & Maximum & 1.00 & 0.42 & 0.20 & 0.62 & 0.02 & 0.01 \\
\hline & \multirow{3}{*}{$\begin{array}{l}\text { Unlock } \\
\text { phase }\end{array}$} & Mean & 1.18 & 0.47 & 0.18 & 0.64 & 0.05 & 0.02 \\
\hline & & Minimum & 1.07 & 0.31 & 0.10 & 0.47 & 0.04 & 0.01 \\
\hline & & Maximum & 1.38 & 0.61 & 0.27 & 0.77 & 0.07 & 0.03 \\
\hline \multirow{9}{*}{$\begin{array}{c}\text { HQ } \\
\text { Ingestion } \\
\text { (Adult) }\end{array}$} & \multirow{3}{*}{$\begin{array}{c}\text { Pre } \\
\text { lockdown }\end{array}$} & Mean & 3.79 & 0.58 & 0.53 & 0.83 & 0.12 & 0.03 \\
\hline & & Minimum & 3.05 & 0.43 & 0.37 & 0.68 & 0.06 & 0.02 \\
\hline & & Maximum & 4.48 & 0.73 & 0.67 & 0.95 & 0.19 & 0.03 \\
\hline & During & Mean & 0.50 & 0.18 & 0.07 & 0.32 & 0.01 & 0.01 \\
\hline & \multirow[t]{2}{*}{ lockdown } & Minimum & 0.38 & 0.07 & 0.02 & 0.25 & 0.01 & 0.00 \\
\hline & & Maximum & 0.61 & 0.25 & 0.12 & 0.38 & 0.01 & 0.01 \\
\hline & \multirow{3}{*}{$\begin{array}{l}\text { Unlock } \\
\text { phase }\end{array}$} & Mean & 0.72 & 0.29 & 0.11 & 0.39 & 0.03 & 0.01 \\
\hline & & Minimum & 0.66 & 0.19 & 0.06 & 0.29 & 0.02 & 0.01 \\
\hline & & Maximum & 0.85 & 0.38 & 0.16 & 0.47 & 0.04 & 0.02 \\
\hline \multirow{9}{*}{$\begin{array}{c}\text { HQ } \\
\text { Dermal } \\
\text { (Children) }\end{array}$} & \multirow{3}{*}{$\begin{array}{c}\text { Pre } \\
\text { lockdown }\end{array}$} & Mean & $2.03 \mathrm{E}-02$ & $5.21 \mathrm{E}-03$ & $1.91 \mathrm{E}-02$ & $1.49 \mathrm{E}-02$ & $2.16 \mathrm{E}-04$ & $2.46 \mathrm{E}-04$ \\
\hline & & Minimum & $1.63 \mathrm{E}-02$ & $3.83 \mathrm{E}-03$ & $1.31 \mathrm{E}-02$ & $1.22 \mathrm{E}-02$ & $1.02 \mathrm{E}-04$ & $1.97 \mathrm{E}-04$ \\
\hline & & Maximum & $2.40 \mathrm{E}-02$ & $6.49 \mathrm{E}-03$ & $2.41 \mathrm{E}-02$ & $1.70 \mathrm{E}-02$ & 3.32E-04 & $2.91 \mathrm{E}-04$ \\
\hline & \multirow{3}{*}{$\begin{array}{c}\text { During } \\
\text { lockdown }\end{array}$} & Mean & $2.71 \mathrm{E}-03$ & $1.59 \mathrm{E}-03$ & $2.58 \mathrm{E}-03$ & $5.76 \mathrm{E}-03$ & $1.67 \mathrm{E}-05$ & $4.85 \mathrm{E}-05$ \\
\hline & & Minimum & $2.04 \mathrm{E}-03$ & $6.28 \mathrm{E}-04$ & $8.75 \mathrm{E}-04$ & $4.38 \mathrm{E}-03$ & $1.02 \mathrm{E}-05$ & 4.05E-05 \\
\hline & & Maximum & $3.27 \mathrm{E}-03$ & $2.28 \mathrm{E}-03$ & 4.30E-03 & $6.76 \mathrm{E}-03$ & $2.30 \mathrm{E}-05$ & $5.14 \mathrm{E}-05$ \\
\hline & \multirow{3}{*}{$\begin{array}{l}\text { Unlock } \\
\text { phase }\end{array}$} & Mean & $3.86 \mathrm{E}-03$ & $2.56 \mathrm{E}-03$ & $3.91 \mathrm{E}-03$ & $7.00 \mathrm{E}-03$ & $5.71 \mathrm{E}-05$ & $1.04 \mathrm{E}-04$ \\
\hline & & Minimum & $3.52 \mathrm{E}-03$ & $1.70 \mathrm{E}-03$ & $2.19 \mathrm{E}-03$ & $5.14 \mathrm{E}-03$ & 3.83E-05 & $6.20 \mathrm{E}-05$ \\
\hline & & Maximum & $4.54 \mathrm{E}-03$ & $3.36 \mathrm{E}-03$ & $5.83 \mathrm{E}-03$ & $8.47 \mathrm{E}-03$ & 7.40E-05 & $1.45 \mathrm{E}-04$ \\
\hline \multirow{9}{*}{$\begin{array}{l}\text { HQ } \\
\text { Dermal } \\
\text { (Adult) }\end{array}$} & \multirow{3}{*}{$\begin{array}{c}\text { Pre } \\
\text { lockdown }\end{array}$} & Mean & $1.19 \mathrm{E}-02$ & $3.04 \mathrm{E}-03$ & $1.12 \mathrm{E}-02$ & $8.72 \mathrm{E}-03$ & $1.26 \mathrm{E}-04$ & $1.44 \mathrm{E}-04$ \\
\hline & & Minimum & $9.55 \mathrm{E}-03$ & $2.24 \mathrm{E}-03$ & 7.67E-03 & $7.12 \mathrm{E}-03$ & $5.97 \mathrm{E}-05$ & $1.15 \mathrm{E}-04$ \\
\hline & & Maximum & $1.40 \mathrm{E}-02$ & $3.79 \mathrm{E}-03$ & $1.41 \mathrm{E}-02$ & $9.93 \mathrm{E}-03$ & $1.94 \mathrm{E}-04$ & $1.70 \mathrm{E}-04$ \\
\hline & During & Mean & $1.58 \mathrm{E}-03$ & $9.27 \mathrm{E}-04$ & $1.51 \mathrm{E}-03$ & $3.37 \mathrm{E}-03$ & $9.76 \mathrm{E}-06$ & $2.83 \mathrm{E}-05$ \\
\hline & \multirow[t]{2}{*}{ lockdown } & Minimum & $1.19 \mathrm{E}-03$ & $3.67 \mathrm{E}-04$ & $5.11 \mathrm{E}-04$ & $2.56 \mathrm{E}-03$ & $5.97 \mathrm{E}-06$ & $2.36 \mathrm{E}-05$ \\
\hline & & Maximum & $1.91 \mathrm{E}-03$ & $1.33 \mathrm{E}-03$ & $2.51 \mathrm{E}-03$ & $3.95 \mathrm{E}-03$ & $1.34 \mathrm{E}-05$ & $3.00 \mathrm{E}-05$ \\
\hline & \multirow{3}{*}{$\begin{array}{l}\text { Unlock } \\
\text { phase }\end{array}$} & Mean & $2.26 \mathrm{E}-03$ & $1.50 \mathrm{E}-03$ & $2.29 \mathrm{E}-03$ & $4.09 \mathrm{E}-03$ & $3.34 \mathrm{E}-05$ & $6.06 \mathrm{E}-05$ \\
\hline & & Minimum & $2.06 \mathrm{E}-03$ & $9.96 \mathrm{E}-04$ & $1.28 \mathrm{E}-03$ & $3.01 \mathrm{E}-03$ & $2.24 \mathrm{E}-05$ & $3.62 \mathrm{E}-05$ \\
\hline & & Maximum & $2.65 \mathrm{E}-03$ & $1.96 \mathrm{E}-03$ & $3.41 \mathrm{E}-03$ & $4.95 \mathrm{E}-03$ & 4.33E-05 & $8.48 \mathrm{E}-05$ \\
\hline
\end{tabular}


Table 4: One way ANOVA for significance test of Hazard Index (HI) values

\begin{tabular}{|c|c|c|c|c|c|c|}
\hline Variable & & $\begin{array}{l}\text { Sum of } \\
\text { Squares }\end{array}$ & $\mathrm{df}$ & $\begin{array}{l}\text { Mean } \\
\text { Square }\end{array}$ & $\mathrm{F}$ & Sig. \\
\hline \multirow{3}{*}{$\begin{array}{l}\text { Ingestion } \\
\text { (children) }\end{array}$} & Between Groups & 458.196 & 2 & 229.098 & 242.907 & 0.000 \\
\hline & Within Groups & 28.295 & 30 & 0.943 & & \\
\hline & Total & 486.490 & 32 & & & \\
\hline \multirow{3}{*}{$\begin{array}{l}\text { Ingestion } \\
\text { (Adult) }\end{array}$} & Between Groups & 154.542 & 2 & 77.271 & 235.978 & 0.000 \\
\hline & Within Groups & 9.824 & 30 & 0.327 & & \\
\hline & Total & 164.366 & 32 & & & \\
\hline \multirow{3}{*}{$\begin{array}{l}\text { Dermal } \\
\text { (children) }\end{array}$} & Between Groups & 0.015 & 2 & 0.007 & 198.054 & 0.000 \\
\hline & Within Groups & 0.001 & 30 & 0.000 & & \\
\hline & Total & 0.016 & 32 & & & \\
\hline \multirow{3}{*}{$\begin{array}{l}\text { Dermal } \\
\text { (Adult) }\end{array}$} & Between Groups & 0.005 & 2 & 0.003 & 198.054 & 0.000 \\
\hline & Within Groups & 0.000 & 30 & 0.000 & & \\
\hline & Total & 0.005 & 32 & & & \\
\hline
\end{tabular}




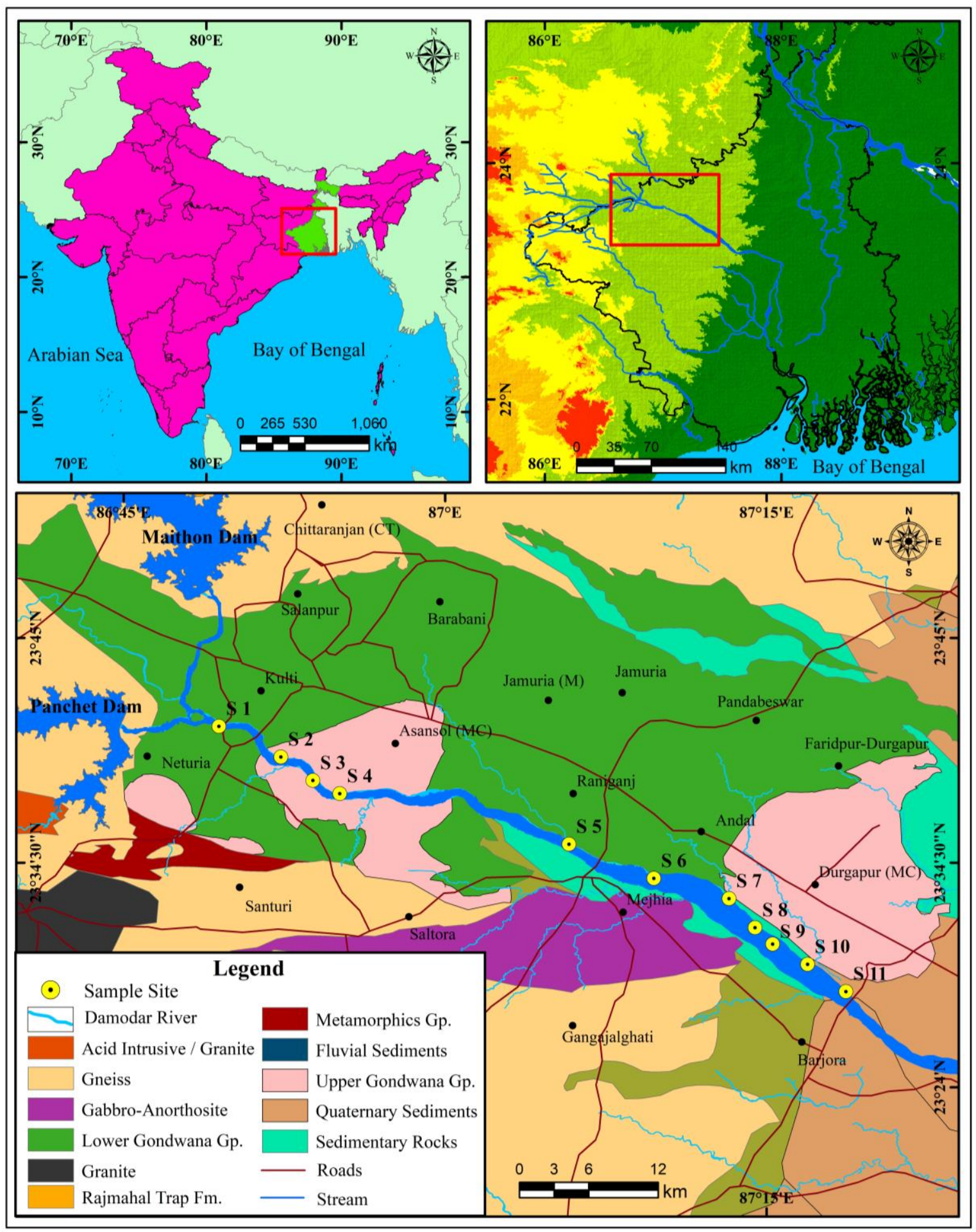

Fig. 1: Location map of the study stretches of river Damodar (India) 


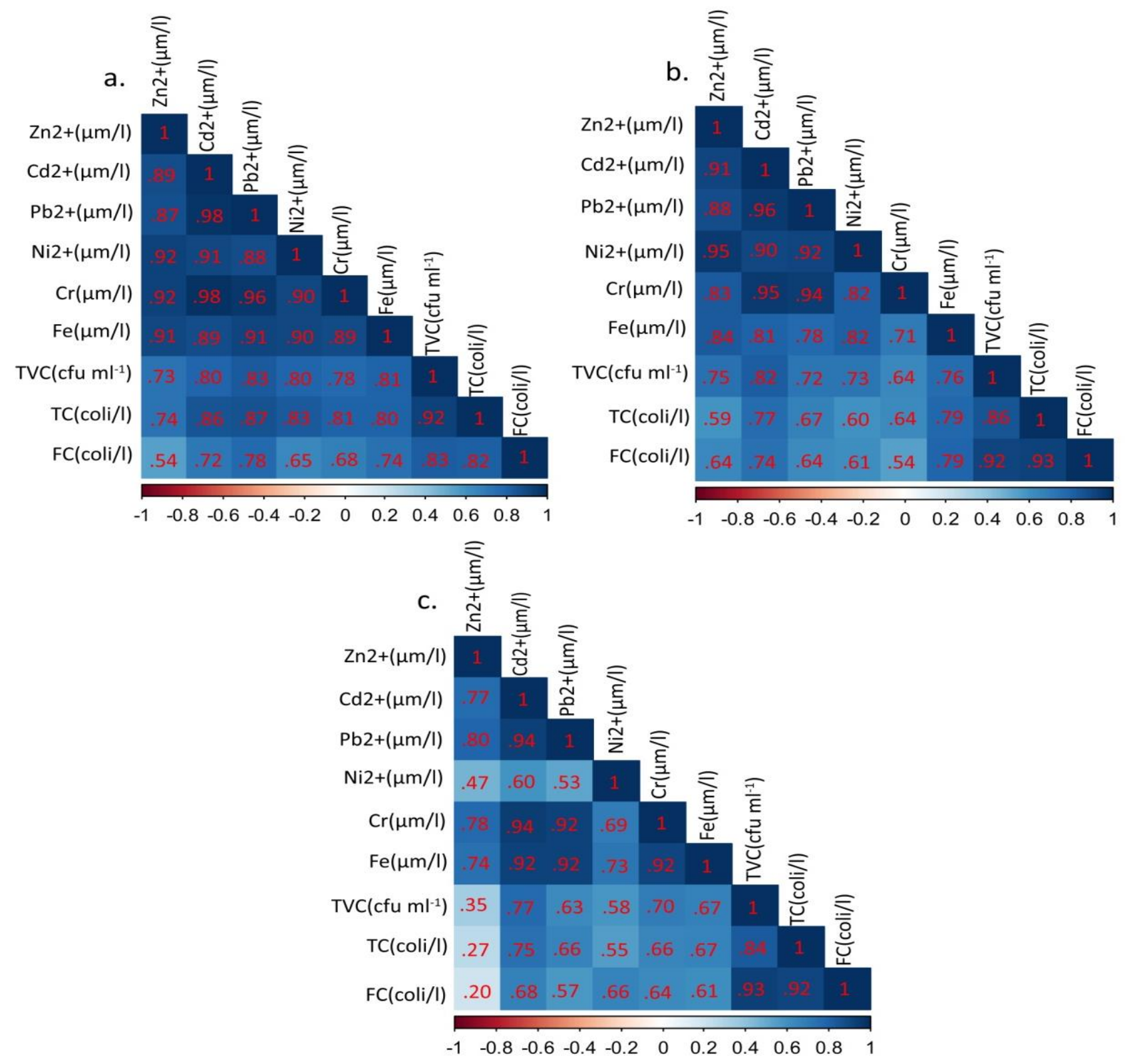

Fig 2: Pearson's Correlation coefficient matrix (at 0.05 level of significance) for a) prelockdown, b) during lockdown and c) unlock phase 

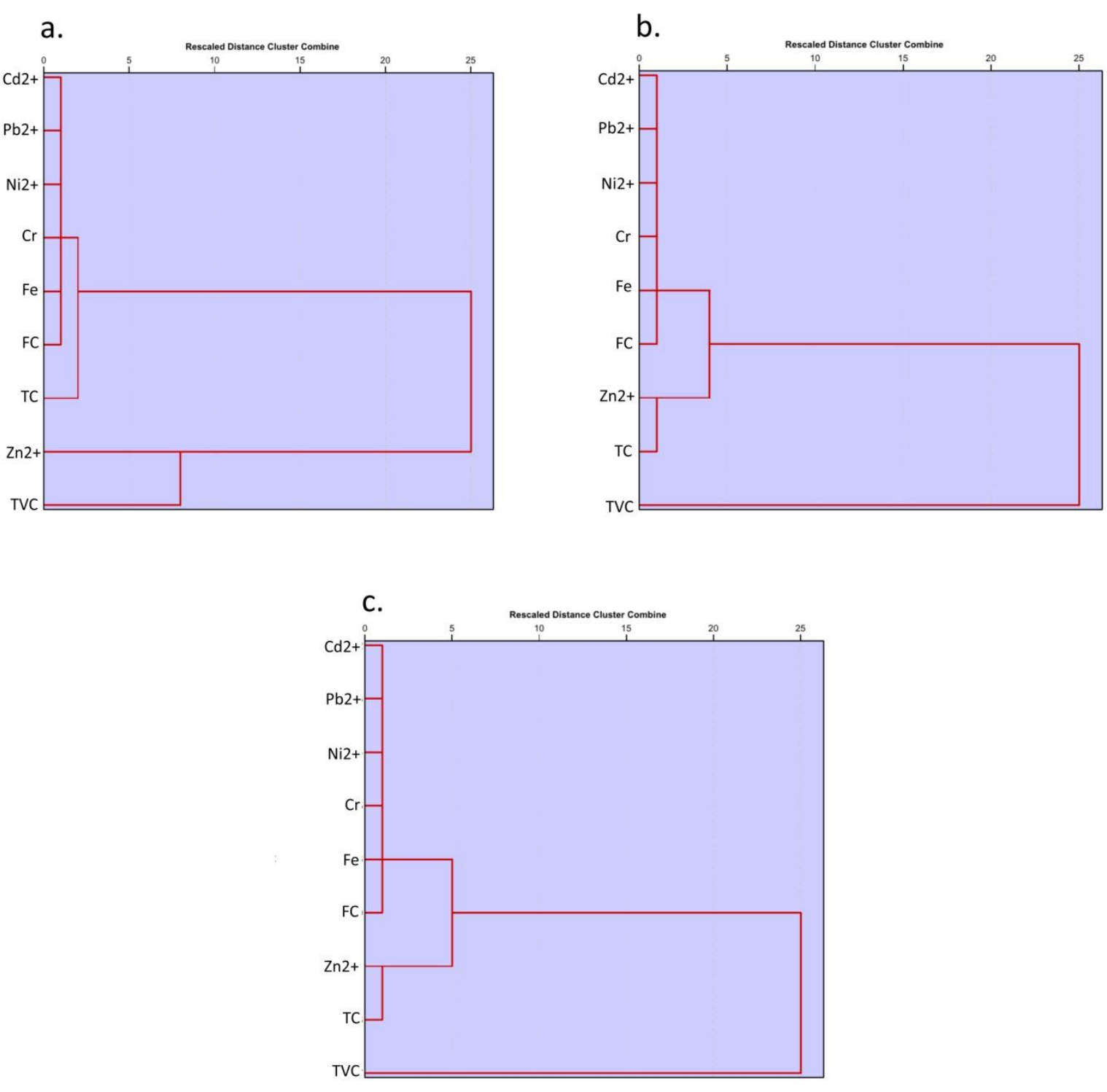

Fig 3: Dendogram of hierarchical cluster analysis of a) pre lockdown, b) lockdown and c) unlock phase 


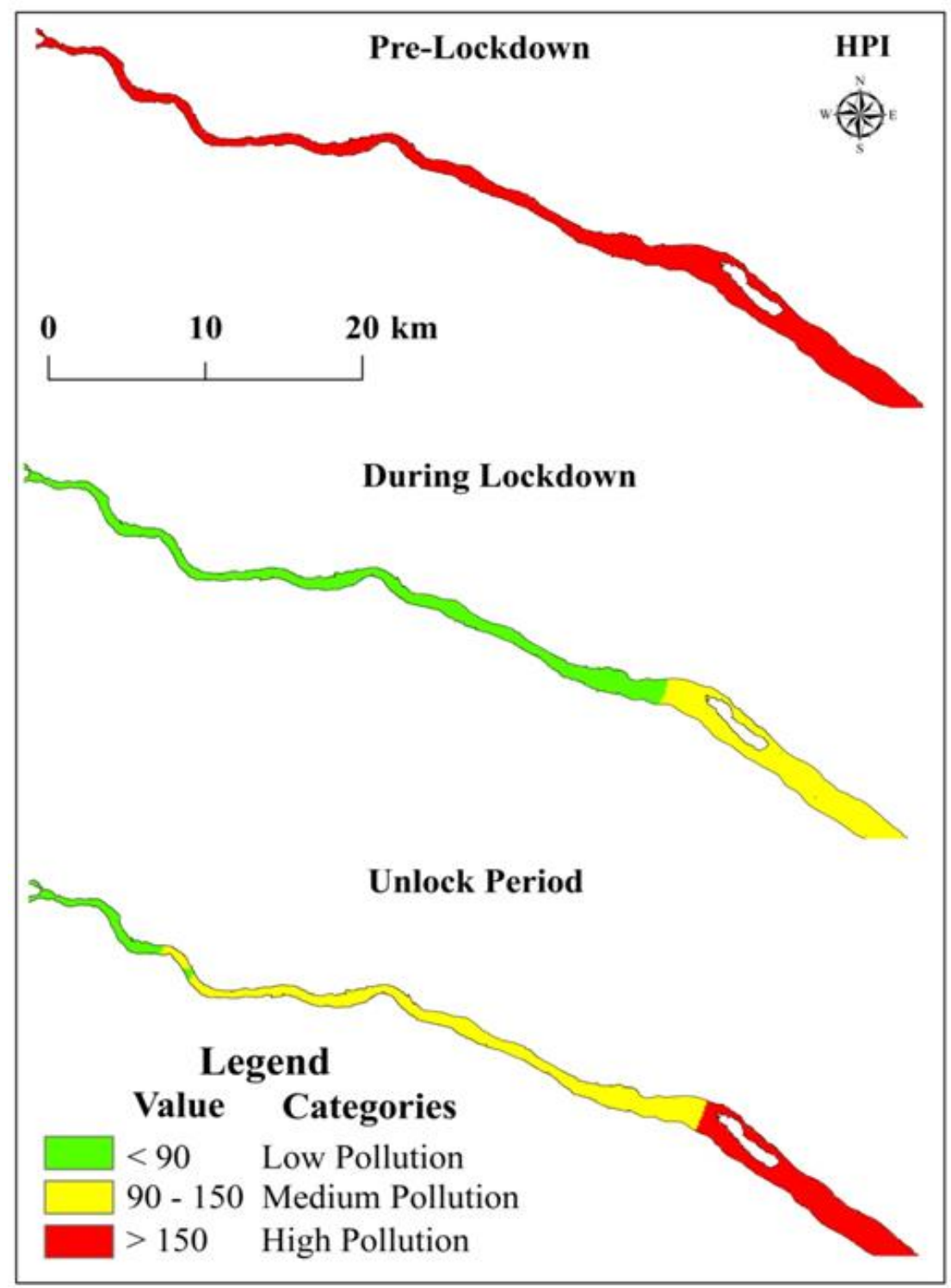

Fig 4: Spatial distribution of HPI in river Damodar. 

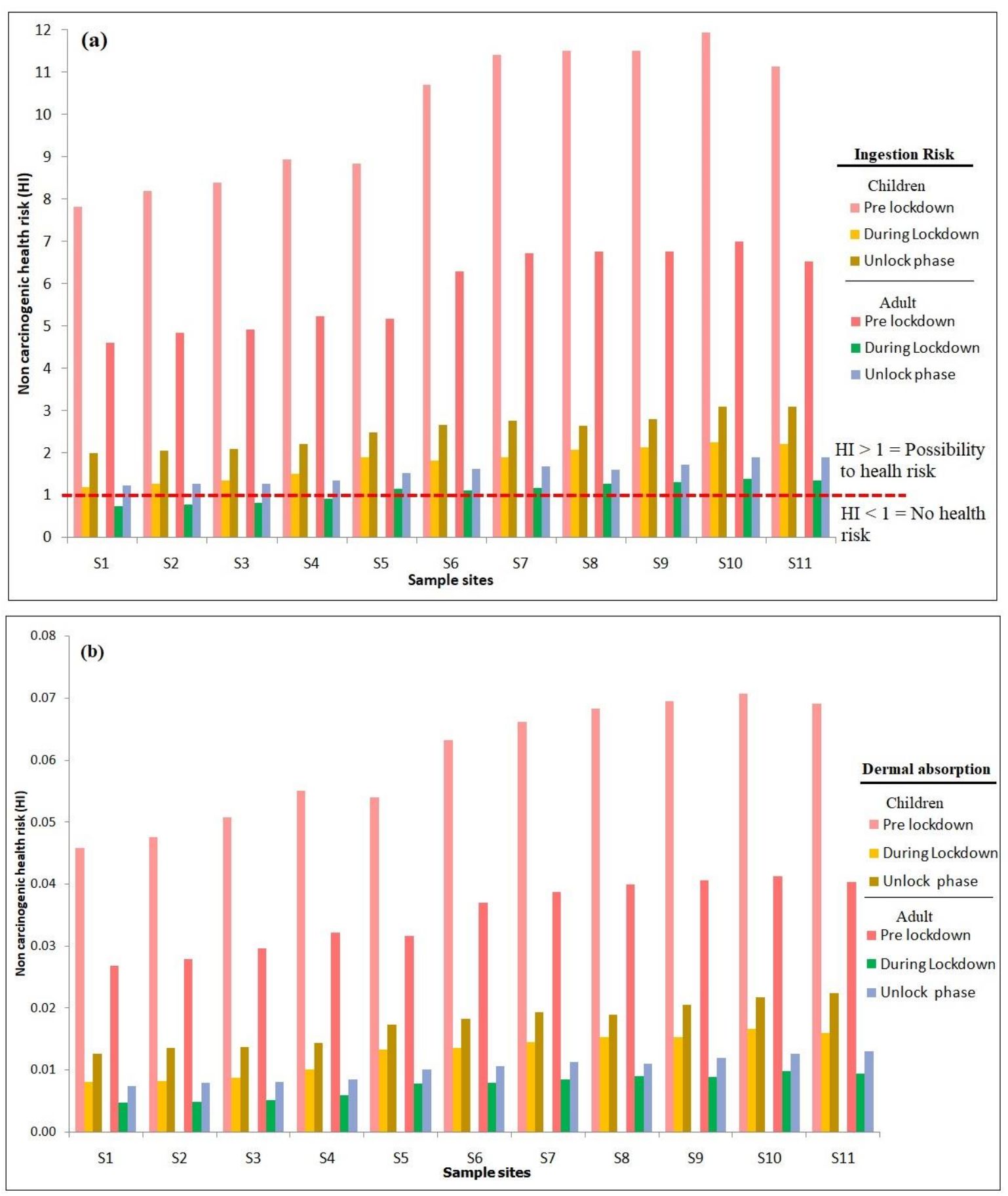

Fig 5: Hazard Index (HI) for children and adult population (non-carcinogenic). (a) Ingestion and (b) Dermal 